Revista Eletrônica Geografar, Curitiba, v. 2, Resumos do VI Seminário Interno de Pós-Graduação em Geografia, p. 66-66. Junho/2007

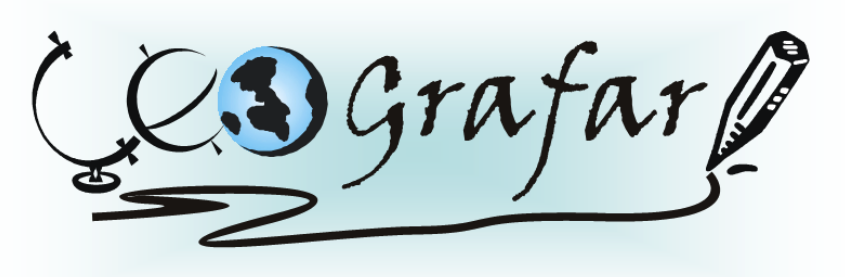

Revista Eletrônica do Programa de Pós-Graduação em Geografia - UFPR

\title{
UNIDADES DE PAISAGEM NO BAIRRO DE SANTA FELICIDADE/CURITIBA - PR. NA ESCALA 1:10000 COM BASE NA HEMEROBIA.
}

\author{
RUDOLF KRÖKER ${ }^{1}$
}

Há milhares de anos o Homem vem moldando uma segunda natureza no seio daquela que encontrou sobre a terra e, desde a Grécia antiga, homem e natureza estão irremediavelmente separados. Todavia, para os pensadores gregos essa transformação não implicaria no total desaparecimento da natureza que já existia antes do surgimento do Homem. Para eles a Natureza sempre existiu e sempre existirá. O desprezo do ser humano para com a natureza, pode ser explicado pela ignorância em relação ao seu funcionamento e benefícios fornecidos, bem como pelos valores da sociedade. Para muitos, cidade e natureza são conceitos opostos. A cidade representaria um meio adaptado às necessidades humanas, sendo a urbanização caracterizada pela substituição dos ecossistemas naturais por centros de grande densidade criados pelo homem, onde a espécie dominante seria a humana e o meio estaria organizado para permitir a sua sobrevivência, gerando diferentes ecossistemas urbanos, que serão nomeados por Unidades de Paisagem seguindo propostas de BERTRAND (1968) e MONTEIRO (1978/2000).Vários conceitos poderiam instruir um acompanhamento e avaliação dessas mudanças no uso e na cobertura da terra. SUKKOP (1972), levando em consideração mudanças no solo, na vegetação/flora, define Hemerobia como a totalidade dos efeitos das ações, voluntárias ou não, do ser humano sobre os. ecossistemas/paisagens classificando-os em relação aos graus de naturalidade e estado hemerobiótico. Portanto, uma possível resposta é a aplicação do conceito de Hemerobia no acompanhamento, delimitação e na avaliação das unidades de paisagens urbanizadas. Este trabalho buscará, colaborar para com o planejamento das paisagens urbanas e também como uma proposição metodológica - na elaboração de um sistema de classificação do estado hemerobiótico para unidades de paisagem em ambientes urbanos. Os objetivos propostos serão aplicados no bairro Santa Felicidade no município de Curitiba, tendo como objetivo último à elaboração da carta de Unidades de Paisagem avaliadas pelo conceito de Hemerobia.

Palavras chave: natureza, hemerobia, planejamento da paisagem.

${ }^{1}$ Mestrando em Geografia - UFPR - email:rudolfkroker@yahoo.com.br Orientador: JOÃO CARLOS NUCCI 